\title{
MENINGKATKAN KEMAMPUAN MENULIS PUISI BEBAS MELALUI "ENVIRONMENT APPROACH LEARNING" SISWA KELAS VIII-A SMP NEGERI 2 GEMPOL
}

\author{
Melisa Puspita Sari ${ }^{1}$, Sri Budi Asturi ${ }^{2}$ \\ SMK 2 Walisongo Gempol-Pasuruan ${ }^{1}$, Program Studi Pendidikan Bahasa \\ Indonesia, Fakultas Ilmu Sosial dan Humaniora Universitas PGRI Adi Buana \\ Surabaya ${ }^{2}$ \\ $\underline{\text { melisapuspitasari@gmail.com }}^{1}, \underline{\text { sri.budi@unipasby.ac.id }}^{2}$
}

\begin{abstract}
ABSTRAK: Berdasarkan hasil pengamatan peneliti, rendahnya keterampilan menulis siswa di kelas VIII- A SMP Negeri 2 Gempol. Khususnya menulis puisi disebabkan oleh beberapa faktor, yaitu: (1) siswa kurang tertarik pada pelajaran menulis puisi bebas di ruang kelas, motivasi siswa mengikuti pembelajaran rendah. Mereka merasa malas menghadapi pelajaran yang membutuhkan imajinasi untuk merangkai kata menjadikan bait-bait puisi. (2) guru kesulitan dalam membangkitkan minat siswa, (3) siswa kesulitan dalam menentukan topik/tema serta mengemukakan ide yang mendukung untuk dikembangkan dalam tulisan untuk membuat puisi bebas (4) guru kesulitan untuk menemukan teknik/metode atau media yang tepat untuk mengajarkan meteri menulis puisi bebas kepada siswa. Tujuan dalam penelitian ini adalah meningkatkan kemampuan menulis puisi bebas melalui Environment Approach Learning siswa kelas VIII-A SMP Negeri 2 Gempol. Sesuai dengan jenis penelitian yang dipilih, yaitu penelitian tindakan kelas, maka penelitian ini menggunakan model penelitian tindakan dari Kemmis dan Taggrat. Hasil penelitian ini menunjukkan bahwa, pembelajaran menulis puisi bebas dengan Environment Approach Learning (pendekatan yang menekankan lingkungan alam), berdampak positif terhadap nilai siswa. Dalam pelaksanaannya guru harus betul-betul menerapkan Environment Approach Learning (pendekatan yang menekankan lingkungan alam), jika ingin memperoleh hasil yang maksimal, karena hasil dari penerapan teknik ini membuktikan bahwa, siswa lebih aktif dan antusias dalam mengikuti pembelajaran. sehingga, nilai siswa meningkat, dari nilai rata-rata 73,20 pada siklus I, menjadi 77 pada siklus II.
\end{abstract}

Kata kunci: menulis puisi bebas, environment approach learning, siswa kelas VIII-A SMP Negeri 2 Gempol

ABSTRACT: Based on the results of observations, the low writing skills of students in class VIII-A SMP Negeri 2 Gempol. In particular, writing poetry is caused by several factors, namely: (1) students are less interested in free poetry writing lessons in the classroom, students' motivation to participate in learning is low. They feel lazy to face lessons that require imagination to string words into 
poetry. (2) the teacher has difficulty in generating student interest, (3) the student has difficulty in determining the topic/theme and proposes supporting ideas to be developed in writing to make poetry (4) the teacher has difficulty finding the right technique/method or media to teach writing material free poetry to students. The purpose of this research is to improve the ability to write free poetry through Environment Approach Learning for students of class VIII-A of SMP Negeri 2 Gempol. In accordance with the type of research chosen, namely classroom action research, this research uses the action research model of Kemmis and Taggrat. The results of this study indicate that learning to write free poetry with the Learning Environment Approach has a positive impact on students' grades. In practice, the teacher really applies the Environment Approach Learning, if you want to get maximum results, because the results of the application of this technique prove that students are more active and enthusiastic in participating in learning. Thus, the student's score increased from an average score of 73.20 in the first cycle to 77 in the second cycle.

Keywords: free poetry writing, environmental approach learning, class VIII-A students of SMP Negeri 2 Gempol

\section{PENDAHULUAN}

Bahasa merupakan sebuah alat komunikasi yang digunakan manusia untuk berinteraksi satu dengan yang lain, untuk menerjemahkan segala kebutuhan manusia dalam kehidupanya. Hal tersebut sejalan dengan pengertian bahasa yang terdapat di Kamus Besar Bahasa Indoneseia sebagai berikut. Bahasa, sistem lambang bunyi yang arbitrer yang dipergunakan oleh para anggota masyarakat untuk bekerja sama, berinteraksi satu sama lain (Novia, 2009:52-53).

Dalam dunia pendidikan, Bahasa Indonesia merupakan salah satu mata pelajaran yang harus dikuasai siswa, karena dengan penguasaan bahasa Indonesia yang baik, siswa akan mempunyai perbendaharaan kata yang memadai, sehingga mempermudah mereka untuk memahami materi setiap mata pelajaran yang disampaikan oleh guru. Hal tersebut dikarenakan oleh, penetapan bahasa Indonesia sebagai bahasa resmi yang digunakan dalam dunia pendidikan mulai jenjang SD, SMP, SMK, hingga perguruan tinggi. Hal tersebut membuktikan bahwa, bahasa Indonesia mempunyai peranan yang sangat penting dalam perkembangan dunia pendidikan.

Ada empat keterampilan dalam pengajaran bahasa Indonesia yang harus dikuasai siswa, meliputi, menyimak, berbicara, membaca, dan menulis. Keempat keterampilan tersebut merupakan sebuah rangkaian yang saling berhubungan satu sama lain.

Menurut hasil pengamatan peneliti, rendahnya keterampilan menulis siswa di kelas VIII- A SMP Negeri 2 Gempol. Khususnya menulis puisi disebabkan oleh beberapa faktor, yaitu: (1) siswa kurang tertarik pada pelajaran menulis puisi bebas di ruang kelas, motivasi siswa mengikuti pembelajaran rendah. Mereka merasa malas menghadapi pelajaran yang membutuhkan imajinasi untuk 
merangkai kata menjadikan bait-bait puisi. (2) guru kesulitan dalam membangkitkan minat siswa, (3) siswa kesulitan dalam menentukan topik/tema serta mengemukakan ide yang mendukung untuk dikembangkan dalam tulisan untuk membuat puisi bebas (4) guru kesulitan untuk menemukan teknik/metode atau media yang tepat untuk mengajarkan meteri menulis puisi bebas kepada siswa.

Siklus I diperoleh hasil kemampuan smenulis puisi bebas siswakelas VIIIA dengan jumlah 42 siswa secara rata-rata yang dicapai sebesar 73,20 (73\%). Hal ini siklus I berada dibawa SKBM yang telah ditentukan, maka dalam penelitian tindakan kelas ini perlu diadakan kegiatan pada siklus yang ke II berikutnya dan dapat dinyatakan belum berhasil atau belum tuntas bahwa situasi belajar di kelas kurang menunjang keberhasilan belajar siswa. Sebab dari 42 siswa, diketahui yang aktif sebanyak 27 siswa, kurang aktif 4 siswa, yang tidak aktif sebanyak 10 siswa dan yang tidak hadir 1 siswa.

Siklus II dapat disimpulkan hasil presentasi belajar siswa dengan jumlah 42 siswa secara rata-rata yang dicapai sebesar (86 \%). Hal ini diatas SKBM yang telah ditentukan, maka dalam penelitian tindakan kelas ini tidak perlu diadakan kegiatan pada siklus berikutnya dan dapat dinyatakan berhasil atau tuntas. Sebab dari 42 siswa, diketahui yang aktif sebanyak 36 siswa, kurang aktif 5 siswa, tidak aktif 0 dan yang tidak hadir 1 siswa.

Pembelajaran yang sesuai untuk karakter siswa yang cenderung kurang aktif tersebut. Peneliti memberikan teknik pembelajaran yang sekiranya mampu untuk membantu proses belajar yang sebelumnya mengalami hambatan-hambatan yang membuat siswa cenderung pasif dan monoton. Hal ini mampu diterapkannya Environment Approach Learning yaitu (pendekatan yang menekankan lingkuan alam) agar pembelajaran mencapai hasil yang optimal.

Berdasarkan latar belakang masalah di atas, maka masalah penelitian ini berfokus pada pertanyaan berikut. Apakah Environment Approach Learning dapat meningkatkan kemampuan menulis puisi bebas pada siswa kelas VIII-A SMP Negeri 2 gempol? Kemudian, tujuan dalam penelitian ini adalah meningkatkan kemampuan menulis puisi bebas melalui Environment Approach Learning siswa kelas VIII-A SMP Negeri 2 Gempol.

\section{A. Pengertian Prestasi Belajar}

\section{Belajar}

Winkel (1984: 24) mengatakan bahwa belajar adalah suatu kreatifitas mental dan psikhis yang berlangsung dalam interaksi dengan lingkungan yang menghasilkan perubahan-perubahan pengetahuan, pemahaman, ketrampilan, dan nilai sikap.

Sedangkan menurut Slameto.

Pengertian belajar adalah suatu proses usaha yang dilakukan individu untuk memperoleh suatu perubahan tingkahlaku yang baru secara keseluruhan, 
sebagai hasil pengalaman individu itu sendiri dalam interaksi dengan lingkungannya (dalam, Djamarah (2011:13).

Dari beberapa pendapat di atas, dapat disipulkan bahwa, belajar adalah proses perubahan tingkah laku yang dilakukan secara sadar, baik itu perubahan pengetahuan, kecakapan, dan perubahan tersebut dilakukan secara berkesinambungan.

\section{Prestasi belajar}

Prestasi belajar adalah sebuah kalimat yang terdiri dari dua kata yaitu prestasi dan belajar. Antara kata prestasi dan belajar mempunyai arti yang berbeda. Oleh karena itu, sebelum pengertian prestasi belajar, ada baiknya pembahasan ini diarahkan pada masing-masing permasalahan terlebih dahulu untuk mendapatkan pemahaman lebih jauh mengenai makna kata prestasi dan belajar. Hal ini juga untuk memudahkan dalam memahami lebih mendalam tentang pengertian prestasi belajar itu sendiri. Hal ini didukung oleh pendapat Djamarah (1994:19) sebagai berikut. Prestasi adalah hasil dari suatu kegiatan yang telah dikerjakan, diciptakan baik secara individu maupun secara kelompok. Didukung juga dengan Dahar (1994:21), prestasi adalah apa yang telah dapat diciptakan, hasil pekerjaan, hasil yang menyenangkan hati yang diperoleh dengan jalan keuletan kerja.

Dari beberapa pendapat di atas, dapat disimpulkan bahwa "Prestasi belajar adalah berubah". dapatlah dikatakan bahwa belajar itu sebagai rangkaian kegiatan jiwa raga, psiko-fisik untuk menuju perkembangan pribadi manusia seutuhnya, yang berarti menyangkut unsur cipta, rasa dan karsa, ranah kognitif, dan psikomotorik.

\section{Hakikat Keterampilan Menulis}

Menulis merupakan suatu keterampilan berbahasa yang dipergunakan untuk berkomunikasi secara tidak langsung, tidak secara tatap muka dengan orang lain. Sebagai bentuk keterampilan berbahasa, menulis merupakan kegiatan yang bersifat mengungkapkan, maksudnya mengungkapkan gagasan, buah pikiran dan perasaan kepada pihak atau orang lain.

Bernard (2010:19) menyatakan bahwa.

Menulis juga mempunyai kemanfaatan yang positif, sebagai berikut:

a. Sarana untuk mengungkapkan diri,

b. Sarana untuk pemahaman,

c. Membantu mengembangkan kepuasan pribadi, kebanggaan danperasaan harga diri,

d. Meningkatkan kesadaran dan penyerapan terhadap lingkungan,

e. Keterlibatan secara bersemangat dan bukanya penerimaan yang pasrah dan mengembangkan suatu pemahaman dan kemampuan menggunakan bahasa. 
Dari uraian di atas, dapat disimpulkan bahwa, keterampilan menulis merupakan keterampilan yang sangat penting, karena banyak sekali manfaat yang dapat diambil. Ketarmpilan menulis tidak bisa berdiri sendiri tanpa dukungan dari ketiga keterampilan berbahasa yang lain (membaca, berbicara dan menyimak).

\section{Pengertian Puisi}

Puisi adalah salah satu cabang sastra yang menggunakan kata-kata sebagai medium penyampaian untuk membuhkan ilusi dan imajinasi. Dengan demikian, sebenarnya puisi merupakan unkapan batin dan pikiran penyair dalam menciptakan sebuah duni berdasarkan pengalaman batin yang digelutinya (dalam Kasnadi, 2008:1).

Dari pendapat di atas, dapat disimpulkan bahwa, puisi adalah salah satu jenis karya sastra berupa rangkaian kata, yang memiliki nilai estetika dan disusun dengan sistematika tertentu.

\section{5. "Environment Approach Learning"}

Environment Approach Learning (pendekatan pembelajaran yang menekankan Lingkungan Alam) merupakan salah satu strategi pembelajaran koopereatif yang dilaksanakan di sekolah-sekolah. Sehubungan dengan pendapat tersebut, Susilana dan Riyana (2007: 175) mengatakan bahwa.

Dari pendapat di atas, dapat disimpulkan bahwa, Environment Approach Learning, adalah salah satu teknik pembelajaran dengan membagi siswa ke dalam kelompok-kelompok kecil, yang menggunakan media alam sekitar sebagai objek, dengan tujuan menumbuhkan daya imajinasi dan kreatifitas siswa dalam menerjemahkan dari setiap objek yang diamatinya, sehingga, tercapailah tujuan pembelajaran.

\section{Teknik Mendiskripsikan Objek}

Penelitian ini di arahkan pada objek penelitian siswa di kelas VIII- A SMP Negeri 2 Gempol untuk memperoleh jawaban atas rumusan masalah yang telah dikemukakan pada Bab I. Objek yang digunakan siswa untuk memperoleh dan mengembangkan imajinasi siswa dalam pembuatan puisi bebas adalah segala sesuatu yang terdapat di sekitar lingkungan sekolah, misalnya, bunga, pohon, suasana alam, dan lain sebagainya, yang semuanya itu akan memudahkan siswa untuk menuangkan imajinasinya dalam pembuatan puisi bebas.

\section{METODE PENELITIAN}

Metode penelitian merupakan salah satu faktor yang menentukan keberhasilan suatu tujuan yang hendak dicapai dalam setiap penelitian. Suatu penelitian baru dianggap valid dan benar apabila penelitian itu menggunakan metode-metode yang dapat dipertanggung jawabkan kebenarannya. Hal ini senada 
dengan pendapat Arikunto (1998: 151) mengatakan metode penelitian adalah cara yang digunakan oleh peneliti untuk mengumpulkan data penelitiannya.

Teknik Environment Approach Learning, adalah salah satu teknik pembelajaran dengan membagi siswa ke dalam kelompok-kelompok kecil, yang menggunakan media alam sekitar sebagai objek, dengan tujuan menumbuhkan daya imajinasi dan kreatifitas siswa dalam menerjemahkan dari setiap objek yang diamatinya, untuk mencapai tujuan pembelajaran. Subjek dalam penelitian ini adalah siswa kelas VIII-A tahun pelajaran 2010 - 2011 sejumlah 42 siswa. Lokasi Penelitian di SMP Negeri 2 Gempol Kab. Pasuruan. Jl. Dau Darmorejo Kepulungan. Telp. (0343) 634141. Teknik pengumpulan data yang digunakan adalah observasi dan tes. Teknik analisis data dalam penelitian ini deskriptif kuantitatif.

Rancangan dalam penelitian ini adalah rancangan penelitian tindakan. Menurut Zuriah (2003:24) penelitian tindakan merupakan proses daur ulang, mulai tahap perencanaan, pelaksanaan tindakan dan pemantauan, refleksi yang mungkin diikuti dengan perencanaan ulang.

Sesuai dengan jenis penelitian yang dipilih, yaitu penelitian tindakan kelas, maka penelitian ini menggunakan model penelitian tindakan dari Kemmis dan Taggrat (dalam Sugiarti, 1997: 6), yaitu bentuk spiral dari siklus yang satu dengan siklus yang berikutnya.

Berikut ini adalah bagan alur penelitian tindakan kelas yang berupa bagan spiral menurut (Sugiarti, 1997: 6):

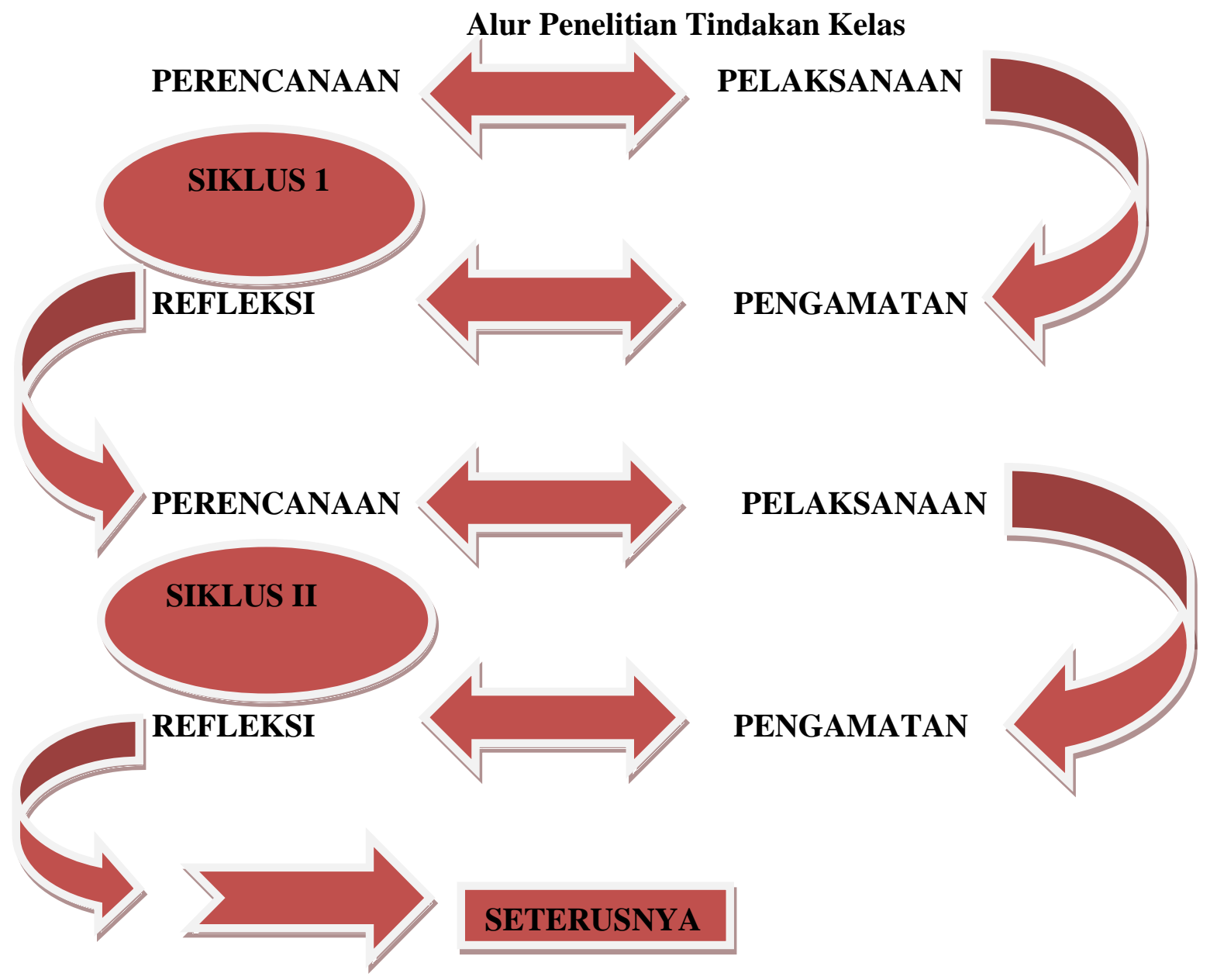


Dari bagan di atas dapat disimpulkan bahwa dalam penelitian ini, penelitian menggunakan dua siklus yang setiap siklusnya meliputi planing (rencana), action (tindakan), observation (pengamatan), dan reflektion (refleksi). Keempat langkah tersebut merupakan satu siklus atau putaran, artinya sesudah langkah ke-4, lalu kembali lagi ke-1 dan seterusnya.

\section{PEMBAHASAN}

Dilihat dari keterlibatan dalam proses pembelajaran Bahasa Indonesia menulis puisi bebas dengan menggunakan "Environment Approach Learning "(pendekatan pembelajaran yang menekankan Lingkungan Alam), siswa cenderung lebih tertarik untuk mengikuti kegiatan pembelajaran yang disampaikan karena siswa lebih mudah memahami materi.

Agar lebih jelasnya dapat dilihat dari grafik pencapaian rata-rata nilai test akhir siswa dan pencapaian prosentase KKM pada pra siklus, siklus I, dan siklus II pada berikut ini.

\section{Gambar Grafik}

\section{Pencapain Rata-Rata Nilai Tes Akhir Siswa Pada Pra Siklus, Siklus 1,} dan Siklus 1 I

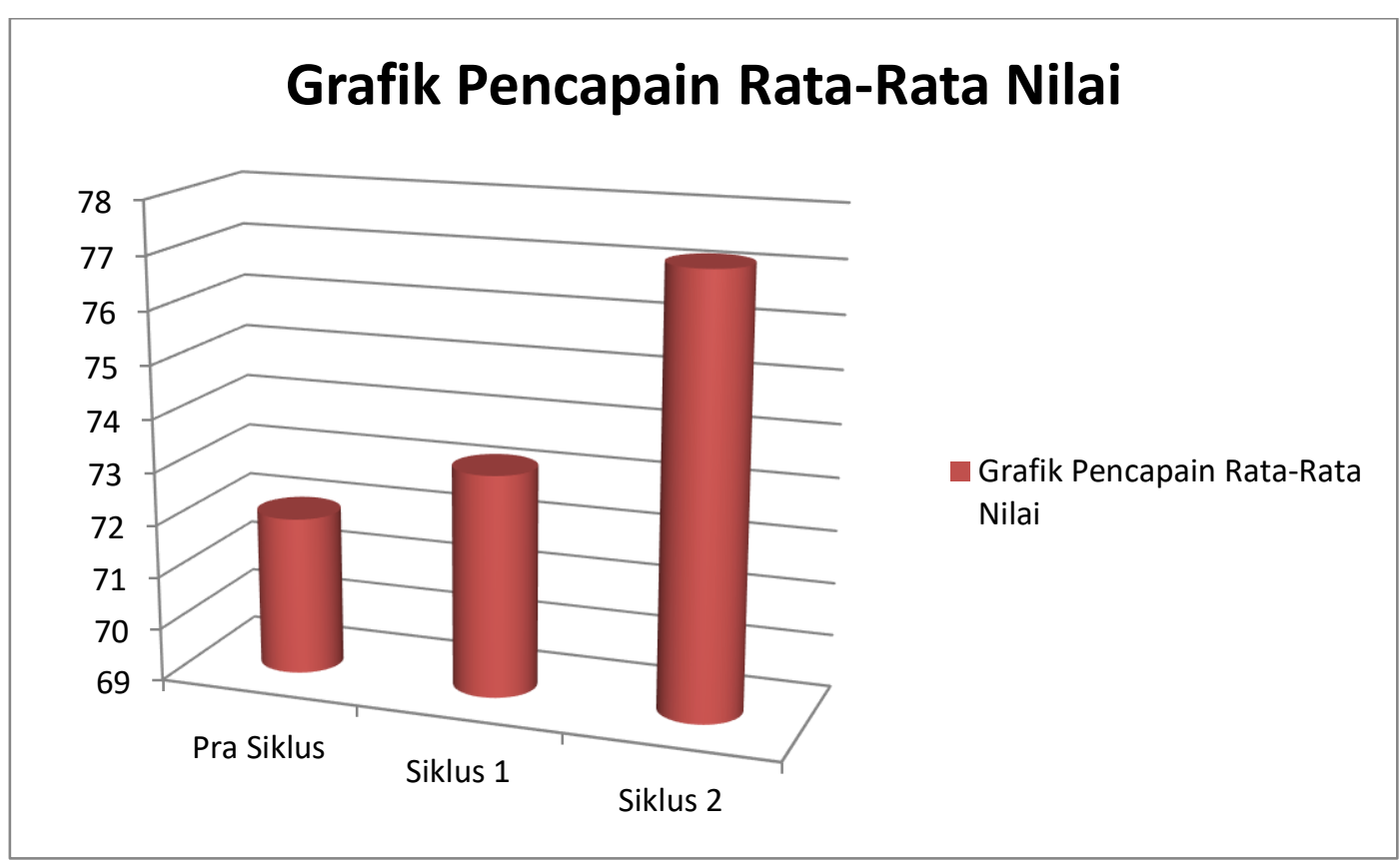

Berdasarkan grafik di atas, dapat terlihat adanya pencapaian yang sangat pesat dari mulai prasiklus, siklus I, dan siklus 2. Dari data grafik di atas tampak adanya pembelajaran yang baik. Hal ini dilihat dari adanya perbedaan skor prasiklus, siklus I, dan siklus 2 yang dicapai oleh sampel penelitian. Skor siklus 2 mengalami peningkatan dari skor siklus I, begitu pula dengan skor siklus I yang mengalami peningkatan dari prasiklus. Jumlah rata-rata nilai prasiklus sebesar 
72,00 sedangkan siklus I jumlah rata-rata siklus I sebesar 73,20 dan nilai rata-rata siklus 2 sebesar 77,17.

Pencapaian Persentase KKM Siswa Pada Pra Siklus, Siklus I, dan Siklus II dapat dilihat pada grafik berikut ini.

\section{Gambar Grafik}

Pencapaian Persentase KKM Siswa Pada Pra Siklus, Siklus I, dan Siklus II

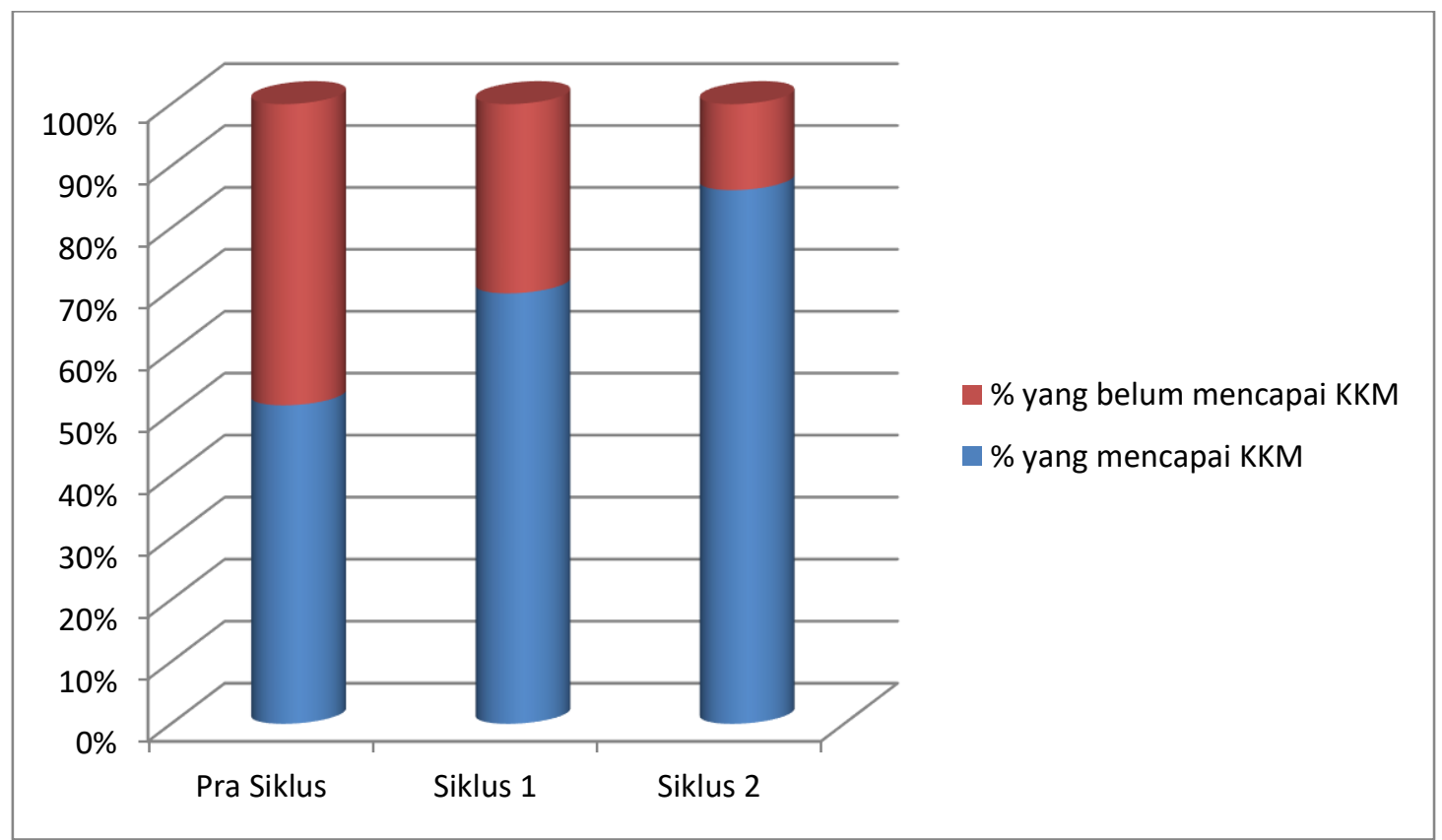

Berdasarkan grafik di atas, dapat terlihat adanya pencapaian yang sangat pesat dari mulai prasiklus, siklus I, dan siklus II. Dari data grafik di atas tampak adanya pembelajaran yang baik. Hal ini dilihat dari adanya perbedaan skor prasiklus, siklus I, dan siklus II yang dicapai oleh sampel penelitian. Skor siklus II mengalami peningkatan dari skor siklus I, begitu pula dengan skor siklus I yang mengalami peningkatan dari prasiklus. Jumlah persentase KKM pada prasiklus sebesar 51,35\%, sedangkan siklus I jumlah persentase KKM sebesar 69,44\%, dan siklus II persentase KKM sebesar $86,11 \%$

Tabel.

Rekapitulasi Nilai Rata-Rata dan KKM

\begin{tabular}{|c|c|c|c|c|}
\hline No & Rekapitulasi & \multicolumn{3}{|c|}{ Siklus } \\
\hline & & Pra & I & II \\
\hline 1. & $\begin{array}{c}\text { Rata-rata } \\
\text { Nilai }\end{array}$ & 72,00 & 73,20 & 77,17 \\
\hline & & Kurang & Cukup & Baik \\
\hline
\end{tabular}




\begin{tabular}{|c|c|c|c|c|}
\hline 2. & $\%$ KKM & 51,35 & 69,44 & 86,11 \\
\hline & & Belum & Belum & Tuntas \\
& & Tuntas & Tuntas & \\
\hline
\end{tabular}

Dari data tabel di atas tampak adanya pembelajaran yang baik. Hal ini dilihat dari adanya perbedaan skor prasiklus, siklus I, dan siklus II yang dicapai oleh sampel penelitian. Skor siklus 2 mengalami peningkatan dari skor siklus I, begitu pula dengan skor siklus I yang mengalami peningkatan dari prasiklus. Jumlah rata-rata nilai prasiklus sebesar 73,92 dan persentase KKM sebesar $51,35 \%$, sedangkan siklus I jumlah rata-rata siklus I sebesar 79,25 dan persentase KKM sebesar 69,44\%, dan nilai rata-rata siklus II sebesar 84,06 dan persentase KKM sebesar $86,11 \%$.

Hasil penelitian ini menunjukkan bahwa, pembelajaran menulis puisi bebas dengan "Environment Approach Learning" (pendekatan yang menekankan lingkungan alam), berdampak positif terhadap nilai siswa. Dalam pelaksanaannya guru harus betul-betul menerapkan "Environment Approach Learning" (pendekatan yang menekankan lingkungan alam), jika ingin memperoleh hasil yang maksimal, karena hasil dari penerapan teknik ini membuktikan bahwa, siswa lebih aktif dan antusias dalam mengikuti pembelajaran. Hal tersebut dibuktikan dengan nilai siswa yang meningkat, dari nilai rata-rata 73,20 pada siklus I, menjadi 77 pada siklus II. Hal ini dapat dikatakan sudah mencapai kreteria ketuntasan belajar.

Hasil observasi kegiatan siswa pada setiap siklus mengalami peningkatan yang akan berakibat meningkatnya nilai siswa. Karena inisiatif maupun ide-ide dari guru sangat mendukung bagi berkembangnya ide siswa untuk selalu imajinatif, kreatif dan aktif dalam mengikuti jalannya proses pembelajaran menulis puisi bebas di kelas. Sehingga, kegiatan pembelajaran berjalan lebih aktif melalui bimbingan dan motivasi terhadap siswa, untuk tampil lebih berani.

\section{SIMPULAN}

Dari hasil penelitian dan pembahasan dapat disimpulkan bahwa, penggunaan Environment Approach Learning (pendekatan yang menekankan lingkungan alam), dapat meningkatkan kualitas pembelajaran, dan meningkatkan kemampuan siswa dalam membuat puisi. Sehingga, nilai siswa mengalami peningkatan dan mencapai batas minimal yang telah ditentukan. Hasil penelitian ini menunjukkan bahwa, pembelajaran menulis puisi bebas dengan Environment Approach Learning (pendekatan yang menekankan lingkungan alam), berdampak positif terhadap nilai siswa. Dalam pelaksanaannya guru harus betul-betul menerapkan Environment Approach Learning (pendekatan yang menekankan lingkungan alam), jika ingin memperoleh hasil yang maksimal, karena hasil dari penerapan teknik ini membuktikan bahwa, siswa lebih aktif dan antusias dalam mengikuti pembelajaran. sehingga, nilai siswa meningkat, dari nilai rata-rata 
73,20 pada siklus I, menjadi 77 pada siklus II. Hal ini dapat dikatakan sudah mencapai kreteria ketuntasan belajar.

\section{DAFTAR PUSTAKA}

Aminudin. 2009. Pengantar Apresiasi Karya Sastra. Bandung: Sinar Baru Algensindo.

Djamarah, dkk. 2010. Strategi Belajar Mengajar. Jakarta: Rineke Cipta.

Novia, Windy. 2009. Kamus Besar Bahasa Indonesia. Surabaya: Kashiko Surabaya.

Syaiful Bahri. 2011. Psikologi Belajar. Jakarta: Rineke Cipta.

Abdurahman, M. 2003. Pendidikan Bagi Anak Berkesulitan Belajar. Jakarta : Departemen Pendidikan dan Kebudayaan. Lerner.2006.Meningkatkan Efektivitas Belajar. Jakarta : Pustaka Jaya. Shoimin, A. 2014. 68 Model Pembelajaran Inovatif dalam kurikulum 2013. Yogyakarta : ArRuzz Media. Widyamartaya. 2008. Pengertian Menulis . Bandung :Depdikbud 